\title{
THE DIBATAG OR CLARKE'S GAZELLE
}

\author{
By John J. LAwrie
}

In his article "Wild Life in Southern Ethiopia" (Oryx, vol. 1, No. 6, page 288), Captain D. S. Sorrell says that he believes that the dibatag (Ammodorcas clarkei) has never been recorded outside the Mudugh province of Somalia, and that it is in danger of soon becoming extinct. These remarks create a wrong impression, and I write to give some additional information on the distribution of this interesting antelope.

R. E. Drake-Brockman (1910) gave its distribution as throughout the Nogal Valley in Somaliland Protectorate, and the Haud to within a few miles of Obbia on the east coast, Milmil in the west, and the Webi Shebeleh in the south. I know nothing of the present distribution in Ethiopia and Somalia, but the distribution within Somaliland Protectorate, based on recent observations by G. E. Curtis who kindly made his notes available to me, is an area bounded by the southern frontier of the Protectorate and a line running from Dawa Ali $\left(8^{\circ} \mathbf{5 5 ^ { \prime }} \mathrm{E}\right.$., $44^{\circ} 15^{\prime}$ N.) through Eik ( $8^{\circ} 58^{\prime}$ E., $45^{\circ} 20^{\prime}$ N.), Ber $\left(9^{\circ} 22^{\prime}\right.$ E., $45^{\circ} 47^{\prime}$ N.), El Dab ( $8^{\circ} 57^{\prime}$ E., $46^{\circ} 31^{\prime}$ N.), Wudwud $\left(8^{\circ} 27^{\prime}\right.$ E., $46^{\circ} 38^{\prime} \mathrm{N}$.), and south to the frontier. A small-scale sketch-map giving a similar distribution has been published by J. A. Hunt (1951). The dibatag has apparently completely disappeared from the Nogal Valley.

The distribution of the dibatag seems to be governed by the occurrence of several species of Commiphora (Drake-Brockman). Though not a grass-eater it may often be seen on the open plains, but always within reach of its favourite shrubs. Within its localities the dibatag is often plentiful, and may be the most common antelope. The main threat to its existence is the destruction of its habitat by excessive grazing. This may be what has happened in the Nogal Valley.

\section{REFERENCES}

Drake-Brockman, R. E. The Mammals of Somaliland. Hurst and Blackett, London, 1910.

Hunt, J. A. A General Survey of the Somaliland Protectorate, 1944-1950. Crown Agents for the Colonies, London, 1951. 